\title{
Response to Early Treatment of Chlormequat Chloride in Cotton (Gossypium hirsutum L.)
}

\author{
Volkan Mehmet ÇINAR ${ }^{1}$ (D), Aydın ÜNAY² \\ ${ }^{1}$ Aydın Adnan Menderes University, Institute of Natural and Applied Sciences, Aydın, Turkey \\ ${ }^{2}$ Aydın Adnan Menderes University, Faculty of Agriculture, Department of Field Crops, Aydın, Turkey
}

\begin{abstract}
Plant growth regulators such as mepiquat chloride (MC) and chlormequat chloride (CCC) are used to establish the balance between the vegetative and generative growth in cotton. This study was conducted to compare the different doses and application time of CCC with MC and un-treatment (control). The seven treatments including control (non-treatment), T1 (three sprays of chlormequat chloride), T2 (two sprays of mepiquat chloride), T3 (0.4 L ha-1 CCC), T4 ( $0.5 \mathrm{~L} \mathrm{ha}^{-1} \mathrm{CCC}$ ), T5 (0.6 $\left.\mathrm{L} \mathrm{ha}^{-1} \mathrm{CCC}\right)$ and T6 $\left(0.7 \mathrm{~L} \mathrm{ha}^{-1} \mathrm{CCC}\right)$ were laid out in Randomized Complete Block Design with four replications. The differences among treatments were found to be significant for seed cotton yield (SCY), the number of bolls per plant (N/B), boll weight (BW), plant height (PH), earliness, ginning out-turn (GOT), fiber fineness (FF), specific seed weight (SWt/S), the number seeds per boll (S/B), single seed volume (V/S) and lint yield per boll (LY/B). Finally, a single application of CCC @ 0.7 $L \mathrm{Lh}^{-1}$ at the stage of DAS 90-110 days recorded optimum yield, earliness and fiber characteristics. The effects of early CCC on seed were more important than fiber characteristics.
\end{abstract}

Keywords: plant growth regulator, lint quality, within-boll, mepiquat chloride, yield

\section{Pamuğun (Gossypium hirsutum L.) Erken Uygulanan Chlormequat Chloride'e Tepkisi}

Öz: Pamukta mepiquat chloride (MC) ve chlormequat chloride (CCC) gibi bitki büyüme düzenleyicileri vejetatif ve generative büyüme arasındaki dengeyi oluşturmak için kullanılmaktadır. Bu çalışmada chlormequat chloride (CCC)'in farklı uygulama zamanları ve dozlarının mepiquat chloride (MC) ve control ile karşılaştırılması amaçlanmıştır. T1 (CCC'nin 3 uygulaması), T2 (MC'nin 2 uygulaması), T3 (40 mI da ${ }^{-1}$

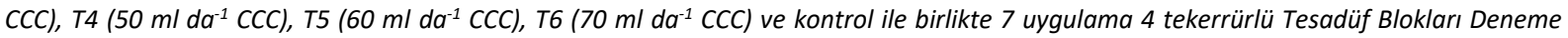
Deseninde karşılaştırılmıştır. Kütlü pamuk verimi, bitkide koza sayısı, koza ağırlığı, bitki boyu, erkencilik, çırçır randımanı, lif inceliği, tohum özgül ağırlığı, kozada tohum sayısı, tohum hacmi ve koza lif verimi yönünden uygulamalar arası farklılıklar önemli bulunmuştur. Sonuçta,

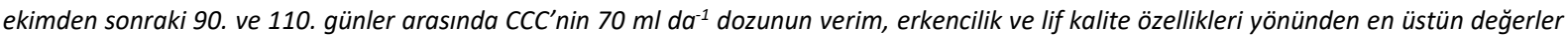
taşıdığı saptanmıştır. Erken dönemde uygulanan CCC uygulamasının verimin lif bileşenlerinden daha çok tohum bileşenlerini etkilediği sonucuna varılmıştır.

Anahtar kelimeler: bitki büyüme düzenleyicisi, lif kalite özellikleri, koza içi verim bileşenleri, mepiquat chloride, verim

\section{INTRODUCTION}

Overgrowth in cotton (Gossypium hirsutum L.) is a common situation, resulting in tall, more leafy plants, which blocks the solar radiation to the lower parts of the plant, with adversely effects on seed cotton yield and harvest machine performance (Lamas, 2001). Moreover, the balance between biomass production and harvest index negatively affected especially in excessive irrigation and nitrogen fertilizer use (Mondino et al., 1999). Plant growth regulators (PGR) are applied to eliminate negative effects and manipulate cotton plant architecture (Echer and Rosolem, 2012) and improve lint yield and fiber quality (Zhao and Oosterhuis, 2000).

The plant growth regulators such as mepiquat chloride (MC) and chlormequat chloride (CCC) extensively used to control the overgrowth of the plant in cotton production areas of Turkey. Mepiquat chloride defined as a synthetic inhibitor into endogenous hormone, whereas chlormequat chloride chemically acts as a gibberellin inhibitor. The important difference between the two plant growth hormones is chlormequat chloride irreversible, whereas plants can grow normally with heavy irrigation, gibberellin application or increasing fertility after overuse of Mepiquat chloride (Chia, 2018).

The short, more compact and open canopy plants and a higher ratio of reproductive to the vegetative dry matter could be provided by the application of PGR (Reddy et al., 1990; Sawan, 2017). Many studies have focused on the differences in application time and doses of PGR to best control vegetative growth and increase seed cotton yield in cotton. Zur et al. (1972) and Karthikeyan and Jayakumar (2001) revealed that seed cotton yield was increased due to the spraying of chlormequat chloride at lower concentrations sprayed during the flowering stage. Similarly, the higher seed cotton yield was recorded in spraying of chlormequat twice compared to control and detopping by Keith (2000), Joseph and Johnson (2006) and Shekar et al. (2013). The increased boll number and boll weight on account of more number of sympodia the boll bearing branches of the cotton plant and the reduced boll shedding per cent in chlormequat chloride sprayed at lower

* Corresponding Author: aunay@adu.edu.tr

The submitted date: 04 Şubat 2021

The accepted date: 23 Mayıs 2021 
concentrations were finally reflected in the productivity of seed cotton. A considerable number of studies comparing mepiquat chloride (MC) and chlormequat chloride (CCC) have been widely reported in cotton, but little study has been carried out with lower and multiple doses of chlormequat chloride at the early growth stage. This study was arranged to evaluate the effects of $M C$ and CCC on cotton yield, within-boll yield components and fiber quality characters to fill inadequate information and confirm the applicability of earlier researches.

\section{MATERIAL AND METHODS}

The field study was conducted at farmer condition in Germencik/Aydın (37.87 N, 27.60 E) during 2019. The field soil was sandy-loam having strongly alkaline (8.42), very low organic matter $(0.73 \%)$, low potassium, moderate phosphorus and sodium, higher calcium and boron. Average air temperature $\left({ }^{\circ} \mathrm{C}\right)$ and total precipitation $(\mathrm{mm})$ from May to October during 2019 and the long-term were presented in Table 1 . The months with the higher average temperature for 2019 were August and July, respectively. Besides, July and August had minimum monthly precipitation. Maximum temperature values of June, July and August during the cotton growing season in the experimental year were above $40{ }^{\circ} \mathrm{C}$. Also, it was seen that the minimum temperature of August, September and October tend to increase against optimum temperature requirements for cotton. Seedbed preparation was operated with conventional tillage, plough and harrow in early spring. Weeds were controlled by both preemergence and post-emergence herbicides. The experiment was arranged in a Randomized Complete Block Design (RCBD) with four replications and seven treatments including control (non-treatment), T1 (three sprays of Chlormequat chloride), T2 (two sprays of mepiquat chloride), T3, T4, T5 and T6 (different doses of chlormequat chloride). Each sub-subplot has a $25 \mathrm{~m}$ length, 8 rows and $140 \mathrm{~m}^{2}$. Sowing was done on April 27 at 150 thousand plants ha ${ }^{-1}(0.7 \mathrm{~m} \times 0.08 \mathrm{~m})$ using Gloria cotton cultivar (Gossypium hirsutum L.). For all parcels, the recommended fertilizer rate of 180:60:60 of NPK was applied using a compound fertilizer (NPK 15:15:15) before sowing as basal application and urea $(46 \% \mathrm{~N})$ to supply the remaining dose of nitrogen before the first irrigation. Chlormequat chloride
(CCC) for T1 treatments applied at $30 \%$ squaring stage $(0.1 \mathrm{~L}$ $\left.\mathrm{ha}^{-1}\right)$, beginning of flowering stage $\left(0.2 \mathrm{~L} \mathrm{ha}^{-1}\right)$ and $90-110$ days after sowing $\left(0.5 \mathrm{~L} \mathrm{ha}^{-1}\right)$. Other CCC treatments (T3, T4, $\mathrm{T} 5$ and T6) were four concentrations $(0.4,0.5,0.6$ and $0.7 \mathrm{~L}$ $\mathrm{ha}^{-1}$ ) of CCC with single spray at 90-100 days after sowing. Mepiquat chloride (MC) with two sprays (T2) was applied during the flowering stage $\left(0.9 \mathrm{~L} \mathrm{ha}^{-1}\right)$ and 3-4 weeks after this stage $\left(0.6 \mathrm{~L} \mathrm{ha}^{-1}\right)$ as recommended. CCC and MC treatments were applied with a portable hand-held field plot sprayer at $250 \mathrm{kPa}$ pressure using a water carrier volume of $400 \mathrm{~L} \mathrm{ha}^{-1}$. The crop was irrigated four times. The spider mite, empoasca, aphid and whitefly ( 3 times) and bollworm (1 time) were controlled by insecticides. Before harvest, the harvest aid chemicals, boll openers (ethephon + cyclanilide) and defoliant (Thidiazuron + Diuron) were applied. Seed cotton yield $\left(\mathrm{kg} \mathrm{ha}^{-1}\right)$ was recorded from the central four rows of each plot $\left(70 \mathrm{~m}^{2}\right)$ leaving the outside rows as borders. Fifteen successive and uniform plants of each replicate were tagged and plant height $(\mathrm{cm})$ and boll number per plant were recorded. The boll weight, ginning out-turn and fiber characteristics (fiber fineness, fiber length and fiber strength) were observed in fifteen randomly selected bolls. Earliness was determined according to the ratio of the opened bolls to the total number of bolls in the other parcel when all bolls of the T2 treatment parcel opened.

Within-boll yield components were calculated by the ontogenetic yield model of Worley et al. (1976). The seeds obtained by ginning from boll samples were delinted with concentrated sulfuric acid. The seed volume was observed by the volumetric displacement of 100 delinted seeds in 13 $\mathrm{mL}$ of ethyl alcohol. The specific seed weight $(\mathrm{Wt} / \mathrm{V} ; \mathrm{mg}$ $\mathrm{mm}^{-3}$ ) was determined by single seed weight $(\mathrm{mg}) /$ single seed volume $\left(\mathrm{V} / \mathrm{S} ; \mathrm{mm}^{3}\right)$. Firstly, seed cotton per seed (SC/S) was calculated from boll weight (BW) / seed number per boll (S/B). Lint cotton/seed (LC/S) was $\mathrm{SC} / \mathrm{S} \times$ ginning out-turn (GO) / 100. The number of fibers per seed $(F / S)$ was calculated with the $(\mathrm{LC} / \mathrm{S}) /(\mathrm{FL} \times \mathrm{FF})$ equation.

Results were statistically analyzed using TARIST statistical Package Program (Acikgoz et al. 1994) as a randomized complete block design. The differences between the means were compared by the least significant difference (LSD) at the $5 \%$ level (Steel et al., 1997).

Table 1. The meteorological data for the cotton growing season during 2019 and long-term

\begin{tabular}{|c|c|c|c|c|c|c|c|c|}
\hline \multirow[t]{2}{*}{ Months } & \multicolumn{2}{|c|}{ Max. temp. $\left({ }^{\circ} \mathrm{C}\right)$} & \multicolumn{2}{|c|}{ Min. temp. $\left({ }^{\circ} \mathrm{C}\right)$} & \multicolumn{2}{|c|}{ Ave. temp. $\left({ }^{\circ} \mathrm{C}\right)$} & \multicolumn{2}{|c|}{ Precipitation (mm) } \\
\hline & 2019 & Long-term & 2019 & Long-term & 2019 & Long-term & 2019 & Long-term \\
\hline May & 37.7 & 35.3 & 9.0 & 9.5 & 21.6 & 21.0 & 11.9 & 38.5 \\
\hline June & 40.4 & 39.8 & 14.9 & 14.2 & 26.9 & 26.0 & 26.9 & 12.9 \\
\hline July & 40.5 & 41.3 & 17.4 & 17.8 & 28.4 & 28.6 & 1.2 & 3.7 \\
\hline August & 41.7 & 40.5 & 19.0 & 17.9 & 29.3 & 28.1 & 0.0 & 4.0 \\
\hline September & 35.9 & 37.5 & 13.9 & 12.9 & 24.4 & 23.9 & 16.6 & 13.4 \\
\hline October & 35.1 & 32.6 & 11.5 & 7.5 & 21.4 & 18.8 & 29.4 & 40.3 \\
\hline
\end{tabular}




\section{RESULTS AND DISCUSSIONS}

The results of the variance analysis of yield and yield components and fiber quality characters presented in Table 2 and 3 , respectively. The differences among treatments were significant for seed cotton yield (SCY), the number of bolls per plant (N/B), boll weight (BW), plant height $(\mathrm{PH})$, earliness, ginning out-turn (GOT) and fiber fineness (FF). Similarly, Shekar et al. (2013) revealed that the differences among control, de-trapping, single and two sprays of CCC for NB and SCY were significant but the effects of CCC on FL, FF and FS were found as non-significant.

Karthikeyan and Jayakumar (2001) had also shown that early spraying of CCC produced an insignificant effect on yield due to low bolls per plant but intermediate spraying (beginning of flowering) was found to yield better. Sawan (2017) emphasized that ginning out-turn, earliness and fiber characteristics were not affected by CCC and daminozide. When the results of our study and the results of previous studies were evaluated together, it was clearly seen that the effect of CCC is not stable.

The mean data and statistically groups of SCY, NB, BW, PH and earliness were given in Table 4. The control together with T6 and T1 were in the same statistically group and these applications recorded the highest seed cotton yield, respectively. Compared to two and three-piece applications as the T1 and T2, respectively, the yield performance of T6 appears superior and economic. When two important efficiency components such as NB and BW were examined, T1 with statistically the lowest NB and the highest BW was remarkable. A similar situation was also valid for plant height and earliness.

As a result of the multiply applications of CCC (T1), the shortest and very early natured plant were formed. Wang et al. (1985), More et al. (1993), Mahmoud et al. (1994) and Sawan (2017) found that the recommended doses and flowering or post-flowering applications of CCC reduced plant height. Also, CCC enhanced earliness in cotton (Pipolo et al., 1993). Although the SCY, NB, BW and PH of the control parcel were highest, earliness was the lowest. It can be said that all applications, whether in multiple and single, had better earliness than control. In terms of all the characteristics studied in Table 4, the T6 stands out with its high performance. GOT values changed from $40.22 \%$ (T1) to $43.99 \%$ (control) in our study. This situation showed the negative effect plant growth inhibitors such as MC and CCC on ginning out-turn. Especially when the data regarding T1 applications were evaluated, it was seen that while GOT decreases, fibers become coarse $(5.24 \mathrm{mic})$. The FL was between $29.56 \mathrm{~mm}$ (T6) and $3139 \mathrm{~mm}$ (T1), while FS values varied from 33.63 (T6) to 35.45 (control). $\mathrm{SCl}$ is a function of $\mathrm{FF}, \mathrm{FL}$ and $\mathrm{FS}$, the coarse fibers of $\mathrm{T} 1$ caused the $\mathrm{SCl}$ to be high for this application. Although it is not statistically significant, it can be said that inhibiting plant growth very early with T1 application may positively affect $\mathrm{FL}$ and FS, and this is reflected in $\mathrm{SCl}$ (Table 5). The fact that plant growth inhibitors such as MC and CCC decrease the ginning out-turn led us to examine the within-boll yield. The differences among the treatments were found to be significant for SWt/S, S/B, V/S and LY/B (Table 6). As expected, seed weight/seed (SWt/S) and volume/seed (V/S) of T1 was superior to control and other treatments (Table 7), whereas S/B was significantly decreased by T1. When $\mathrm{SWt} / \mathrm{S}$ and $\mathrm{V} / \mathrm{S}$ were considered together, it was seen that all treatments except T1 had similar effects.

Table 2. Rapeseed yields by sowing dates, cultivars and seeding rates in 2014/15 and 2015/16 seasons

\begin{tabular}{lllllll}
\hline SOV & df & SCY & NB & BW & PH & Earliness \\
\hline Replication & 3 & 1601.33 & 0.42 & 0.17 & 51.42 & 1.29 \\
Treatment & 6 & $12023.39 * *$ & $11.96^{* *}$ & $0.20^{*}$ & $400.59^{* *}$ & $390.98^{* *}$ \\
Error & 18 & 531.95 & 0.49 & 0.07 & 26.80 & 8.01 \\
Total & 27 & & & & & \\
\hline CV $(\%)$ & & 5.1 & 6.84 & 4.57 & 5.67 & 3.21 \\
\hline
\end{tabular}

${ }^{*}, * *$; significant at $5 \%$ and $1 \%$ probability level, respectively. SCY; seed cotton yield, NB; the number of bolls per plant, BW; boll weight, $\mathrm{PH}$; plant height

Table 3. Results of variance analysis of ginning out-turn and fiber quality

\begin{tabular}{|c|c|c|c|c|c|c|}
\hline SOV & df & GOT & $\mathrm{SCl}$ & $\mathbf{F F}$ & FL & FS \\
\hline Replication & 3 & 0.06 & 68.04 & 0.02 & 1.39 & 1.61 \\
\hline Treatment & 6 & $5.19 * *$ & 47.20 & $0.09 *$ & 1.55 & 6.36 \\
\hline Error & 18 & 0.24 & 45.65 & 0.03 & 0.69 & 3.37 \\
\hline Total & 27 & & & & & \\
\hline CV (\%) & & 1.16 & 4.43 & 3.39 & 2.75 & 5.27 \\
\hline
\end{tabular}


Table 4. Mean of yield, yield components and earliness

\begin{tabular}{llllll}
\hline Treat. & SCY (kg ha-1) & NB (number plant ${ }^{-1}$ ) & BW (g) & PH (cm) & Earliness (\%) \\
\hline Control & $5056.1 \mathrm{a}$ & $11.20 \mathrm{a}$ & $5.75 \mathrm{ab}$ & $95.30 \mathrm{a}$ & $75.00 \mathrm{~d}$ \\
T1 & $4884.7 \mathrm{ab}$ & $6.50 \mathrm{c}$ & $5.82 \mathrm{a}$ & $68.80 \mathrm{~b}$ & $100.00 \mathrm{a}$ \\
T2 & $4766.1 \mathrm{~b}$ & $10.10 \mathrm{~b}$ & $5.34 \mathrm{c}$ & $95.50 \mathrm{a}$ & $95.30 \mathrm{~b}$ \\
T3 & $4250.7 \mathrm{c}$ & $11.60 \mathrm{a}$ & $5.73 \mathrm{ab}$ & $95.50 \mathrm{a}$ & $86.30 \mathrm{c}$ \\
T4 & $4375.7 \mathrm{c}$ & $10.75 \mathrm{ab}$ & $5.31 \mathrm{c}$ & $94.90 \mathrm{a}$ & $85.50 \mathrm{c}$ \\
T5 & $4746.1 \mathrm{~b}$ & $10.70 \mathrm{ab}$ & $5.39 \mathrm{bc}$ & $92.90 \mathrm{a}$ & $83.30 \mathrm{c}$ \\
T6 & $4947.9 \mathrm{ab}$ & $11.08 \mathrm{ab}$ & $5.75 \mathrm{ab}$ & $96.60 \mathrm{a}$ & $98.30 \mathrm{ab}$ \\
LSD & $28.05)$ & 1.04 & 0.38 & 7.69 & 4.21 \\
\hline
\end{tabular}

Means followed by the same letter in each column are not significantly different at $P<0.05$, SCY; seed cotton yield, NB; the number of bolls per plant, BW; boll weight, $\mathrm{PH}$; plant height

Table 5. Mean of ginning out-turn, seed index and fiber characteristics

\begin{tabular}{llllll}
\hline Treat. & GOT (\%) & SCl & FF (mic.) & FL (mm) & FS (g tex $^{-\mathbf{1}}$ ) \\
\hline Control & $43.99 \mathrm{a}$ & 148.75 & $5.00 \mathrm{abc}$ & 29.80 & 35.45 \\
T1 & $40.22 \mathrm{~d}$ & 152.25 & $5.24 \mathrm{a}$ & 31.39 & 35.38 \\
T2 & $42.40 \mathrm{bc}$ & 146.75 & $4.97 \mathrm{bc}$ & 30.58 & 34.45 \\
T3 & $42.31 \mathrm{c}$ & 146.25 & $4.76 \mathrm{c}$ & 30.56 & 34.00 \\
T4 & $42.15 \mathrm{c}$ & 146.75 & $4.91 \mathrm{bc}$ & 30.04 & 34.55 \\
T5 & $43.05 \mathrm{~b}$ & 142.00 & $5.03 \mathrm{ab}$ & 29.91 & 34.28 \\
T6 & $42.54 \mathrm{bc}$ & 143.00 & $4.91 \mathrm{c}$ & 29.56 & 33.63 \\
\hline LSD & $0.05)$ & $\mathrm{ns}$ & 0.26 & $\mathrm{~ns}$ & $\mathrm{~ns}$ \\
\hline
\end{tabular}

Means followed by the same letter in each column are not significantly different at $P<0.05$. GOT; ginning-out turn, $\mathrm{SCl}$; the spinning consistency index, FF; fiber fineness, FL; fiber length, FS; fiber strength

Table 6. Results of variance analysis of within-bolls components

\begin{tabular}{lllllllll}
\hline SOV & df & SWt/S & S/B & V/S & Wt/V & LY/B & LY/S & F/S \\
\hline Block & 3 & 0.00 & 7.92 & 0.000 & 0.006 & 0.058 & 0.000 & 1.229 \\
Application & 6 & $0.00^{*}$ & $9.46^{*}$ & $0.001^{* *}$ & 0.004 & $0.061^{*}$ & 0.000 & 0.555 \\
Error & 18 & 0.00 & 3.51 & 0.000 & 0.007 & 0.022 & 0.000 & 0.684 \\
General & 27 & & & & & & & \\
\hline CV (\%) & & 6.21 & 6.27 & 7.37 & 8.47 & 6.31 & 5.16 & 6.21 \\
\hline
\end{tabular}

$*,{ }^{* *}$; significant at $5 \%$ and $1 \%$ probability level, respectively. SWt/S; seed weight/seed, $\mathrm{S} / \mathrm{B}$; the number seeds per boll, $\mathrm{V} / \mathrm{S}$; volume/seed, Wt/V; seed-specific weight, LY/B; lint yield per boll, LY/S; lint yield per seed, F/S; fibers in the seed

Table 7. Mean of within-bolls components

\begin{tabular}{llllllll}
\hline Treat. & SWt/S (mg) & S/B & V/S (mm $\left.\mathbf{m}^{\mathbf{3}}\right)$ & $\mathbf{W t / V}$ & LY/B (g) & LY/S (mg) & F/S \\
\hline Control & $98.1 \mathrm{~b}$ & $31.1 \mathrm{abc}$ & $103.4 \mathrm{~b}$ & 97.0 & $2.53 \mathrm{a}$ & 80.7 & 13.908 \\
T1 & $125.6 \mathrm{a}$ & $28.0 \mathrm{~d}$ & $128.2 \mathrm{a}$ & 99.3 & $2.34 \mathrm{abc}$ & 85.2 & 12.928 \\
T2 & $98.2 \mathrm{~b}$ & $29.1 \mathrm{bcd}$ & $103.7 \mathrm{~b}$ & 94.8 & $2.27 \mathrm{bc}$ & 80.6 & 13.038 \\
T3 & $95.5 \mathrm{~b}$ & $31.2 \mathrm{ab}$ & $100.1 \mathrm{~b}$ & 97.0 & $2.42 \mathrm{ab}$ & 80.2 & 13.640 \\
T4 & $95.6 \mathrm{~b}$ & $28.0 \mathrm{~d}$ & $95.6 \mathrm{~b}$ & 99.3 & $2.16 \mathrm{c}$ & 80.4 & 13.298 \\
T5 & $98.3 \mathrm{~b}$ & $30.2 \mathrm{abcd}$ & $95.8 \mathrm{~b}$ & 102.3 & $2.32 \mathrm{abc}$ & 78.7 & 12.975 \\
T6 & $95.7 \mathrm{~b}$ & $31.7 \mathrm{a}$ & $95.0 \mathrm{~b}$ & 104.0 & $2.44 \mathrm{ab}$ & 78.2 & 13.500 \\
\hline LSD (0.05) & 9.2 & 2.4 & 11.5 & $\mathrm{~ns}$ & 0.22 & $\mathrm{~ns}$ & $\mathrm{~ns}$ \\
\hline
\end{tabular}

Means followed by the same letter in each column are not significantly different at $P<0.05$. SWt/S; seed weight/seed, S/B; the number seeds per boll, V/S; volume/seed, Wt/V; seed-specific weight, LY/B; lint yield per boll, LY/S; lint yield per seed, F/S; fibers in the seed 
Early sprays as 0.1 and $0.2 \mathrm{~L} \mathrm{ha}^{-1}$ at squaring and flowering stage in T1 treatment increased seed size and seed volume, but this increase was not reflected in the seed-specific weight (Wt/V). On the other hand, it was remarkable that the lint yield per seed (LY/S) increased and the number of fibers in the seed (F/S) was the least in T1 application. It can be said that the moderate LY/B values of the T1 application resulted from the fiber coarseness compared to the others.

\section{CONCLUSIONS}

Based on the results of the present study, the application of CCC @ $0.7 \mathrm{~L} \mathrm{ha}^{-1}$ (T6) performed optimum yield, yield components and fiber characteristics. Hence, $0.7 \mathrm{~L}$ ha ${ }^{-1}$ dose with a single spray of CCC between 90. and 110. days after sowing could be recommended to be a suitable plant growth inhibitor for the cotton growing. Besides, the early application of CCC such as $0.1 \mathrm{~L} \mathrm{ha}^{-1}$ at the stage of square initiation increases seed size and volume rather than fiber properties.

\section{REFERENCES}

Açıkgöz N, Akkaş ME, Moghaddam AF, Özcan K (1994) A Database Based Turkish Statistical Analyses Programme For PC: TARIST. In Field Crop Congress, 25-29 April Plant Breeding Section, İzmir, 2: 264 - 267.

Chia L (2018) What Are The Differences between Mepiquat Chloride and Chlormequat Chloride. Plant Hormones. https://www.plantgrowthhormones.com/info/. Date of access: 24.11.2020

Echer FR, Rosolem CA (2012) Plant Growth Regulator Losses in Cotton as Affected by Adjuvants and Rain. Ciência Rural 42(12): 2138 - 2144.

Joseph TJ, Johnson TP (2006) Effect of Mepiquat Pentaborate on Cotton Cultivars with Different Maturities. The Journal of Cotton Science 10: 128 135.

Karthikeyan PK, Jayakumar, R (2001) Nitrogen and Chlormequat Chloride on Cotton Cultivar. In Plant Nutrition (pp. 806-807). Springer, Dordrecht.

Keith LE (2000) Suggestion For Growth Regulator Use. Crop

Science

Extension.

https://content.ces.ncsu.edu/cotton-

information/suggestions-for-growth-regulator-use.

Date of access: 24.11.2020

Lamas FM (2001) Estudo Comparativo Entre Cloreto De Mepiquat E Cloreto De Chlormequat Aplicados No Algodoeiro. Pesquisa Agropecuária Brasileira 36(2): $265-272$.

Mahmoud MM, Bondok MA, Abdel Halim MA (1994) The Control of Flowering in Cotton Plants in Relation to Induced Growth Correlations. 1- The Use of Some
ÇINAR VM, ÜNAY A Growth Regulators and N Levels on Vegetative and Reproductive Growth. Annals of Agricultural Science 39: 1 - 19.

Mondino MH, Peterlin O, Garay F (1999) Optimization of Yield of Cotton (Gossypium hirsutum L.) by Means of Management of Growth Control with Different Combinations of Densities and Regulation. In Anais II Congresso Brasileiro de Algodao: $O$ algodao no seculo XX, perspectivas para o seculo XXI (pp. 100 - 103). Ribeirao Preto, SP, Brasil, 5-10 Setembro, Campina Grande: Empresa Brasileira de Pesquisa Agropecuaia, Embrapa Algodao.

More PR, Waykar SK, Choulwar SB (1993) Effect of Cycocel (CCC) on Morphological and Yield Contributing Characters of Cotton. Journal Maharashtra Agricultural Universities 18: 294 - 295.

Pipolo AE, Athayde ML, Pipolo VC, Parducci S (1993) Comparison of Different Rates of Chloro Choline Chloride Applied to Herbaceous Cotton. Pesquisa Agropecuaria Brasileira 28: 915 - 923.

Reddy VR, Baker DN, Hodges HF (1990) Temperature and Mepiquat Chloride Effects on Cotton Canopy Architecture. Agronomy Journal 82(2): 190 - 195.

Sawan ZM (2017) Plant Density; Plant Growth Retardants: Its Direct and Residual Effects on Cotton Yield and Fiber Properties. International Journal of Environmental Sciences \& Natural Resources 5(3): 555 $-663$.

Shekar K, Venkataramana M, Devi SS (2013) Effect of Chlormequat Chloride Spray on Bt Cotton Yield with Different Spacings. Madras Agricultural Journal 100(4/6): 429 - 431.

Steel RGD, Torrie JA, Dickey DA (1997) Principles and Procedures of Statistics. A.Biometrical Approach 3rd Edi. Mc Graw Hill Book. INC.

Wang JX, Chem WH, Yu YL (1985) The Yield Increasing Effect of Growth Regulators on Cotton and Their Application. China Cottons 3: 32 - 33.

Worley Jr S, Ramey Jr HH, Harrell DC, Culp TW (1976) Ontogenetic Model of Cotton Yield. Crop Science 16(1): 30 - 34.

Zhao D, Oosterhuis DM (2000) Pix Plus and Mepiquat Chloride Effects on Physiology, Growth, and Yield of Field-Grown Cotton. Journal of Plant Growth Regulation 19(4): $415-422$.

Zur M, Marani A, Kara David B (1972) Effect of Growth Retardants CCC and $\mathrm{CMH}$ on Cotton. Cotton Grow Review 49: 250-257. 
